\title{
Heavy Metal Contamination of Soils around Painted Buildings in Selected Local Governments in Benue and Taraba States of Nigeria
}

\author{
Odo Raphael; Oko, Odiba John and Adelagun Ruth Olubukola Ajoke \\ Department of chemical sciences, Federal University Wukari, Taraba State
}

\begin{abstract}
Soils around painted buildings in Gboko and katsina-Ala (Benue state) and Ibi and Wukari (Taraba State) were collected and analysed for heavy metal contamination using standard methods. The study revealed that the level of contamination in Gboko and Katsina-Ala was in the order of $\mathrm{Pb}>\mathrm{Zn}>\mathrm{Cd}>\mathrm{Cr}$ while for Ibi and Wukari the order was $\mathrm{Pb}>\mathrm{Cd}>\mathrm{Zn}>\mathrm{Cr}$. The levels of contamination of $\mathrm{Mn}$, Ni and $\mathrm{Cu}$ in the soil samples around the painted buildings were low. The high contamination of the soil with lead is a serious threat to man especially the children who play with soils around the environment. Blood monitoring for lead and other metals is therefore recommended for individuals living in and around painted buildings.
\end{abstract}

Keywords: blood monitoring , Contamination, Heavy metals, Painted buildings, soil

\section{Introduction}

For many decades public health authorities have considered mineral contamination of soil and water as a matter of concern [1].Although some metals are essential for life, all metals are toxic at sufficiently high concentrations; for there is a narrow window between what is essential and what is toxic [2].

The persistent accumulation of heavy metals in soil is of great concern because they constitute health threat and toxicity problem to human life and environment. Heavy metal especially $\mathrm{Pb}$ is prominently recognized as a major toxicant due to its adverse effects even at very low concentration [3], and known nutritional, biochemical or physiological benefits or uses or advantages have not yet been established for it. Furthermore, Fergusson [2] , reported that it is almost impossible to find surface soils which can be reasonably described as completely free from $\mathrm{Pb}$-contamination. It was however observed that soil contamination may be considered when concentrations of an element in soils were two-to-three time greater than the average background levels [4]. The health concern for heavy metal contaminated soils arise primarily because of plant uptake, dust or soil ingestion by grazing animals and humans, particularly children. Reports of lead poisoning of children in urban areas due to ingestion of contaminated soils or lead based paints have been presented [5]. $\mathrm{Pb}$ effects on human reproduction, loss of energy and learning ability especially in children have also been well documented [6].The exposure of people to the increasing levels of pollutant metals in various compartments of their environment represents a growing health hazard that is yet to receive due attention. What is worrisome is that many people may be more susceptible to environmental metal poisoning because of their lifestyle and living condition especially as it relates to agricultural practices, vehicular exhausts and bush burning [7].The narrow streets and overcrowding in urban areas, the shelter location of polluting industries, the vibrant outdoor lifestyle, the open type of dwellings, the endemic dusty environment, the prevalence of the contaminated dusts outdoor as well as indoor, poor nutrition and health, poor hygienic practices and various type of painted buildings both private and public buildings can combine to increase the level of exposure and susceptibility to lead and other metal poisoning [8]. Highly elevated $\mathrm{Pb}$ concentrations have been reported in roadside soils and vegetation in Nigeria $[9,10]$.

The discharge of large quantities of toxic metals into soils, air and water inevitably results in the transfer of pollutant metals to the human food chain. An assessment of environmental metal poisoning in Africa especially Nigeria is thus made difficult by the multiplicity of sources in any given area.

House painting is one of the most attractive parts of building in Africa, particularly Nigeria, where many houses are built every year due to increase in the population. Painting is not only limited to the new houses but old houses are also painted and repainted with one form of paint or another. Some companies advertise their product through painting of public and private buildings and other objects along the road or in the strategic places. In view of these developments, painted houses (public, private and any other objects) would represent a major source of trace heavy metals especially in public buildings like schools, churches, and mosques, where some of these buildings are painted and repainted.

Heavy metal poisoning is a medical condition caused by increased level of heavy metals such as lead in the body. Lead interfere with a variety of body processes and is toxic to many organs and tissues including the heart, bones, intestines, kidneys and reproductive and nervous systems. It interfere with the development of the 
nervous system and is therefore toxic particularly to children, causing potentially permanent learning and behaviour disorders, symptoms include abdominal pain, headache, anaemia, irritability, and in severe cases seizures, coma and death.

Routes of exposure to heavy metals include contaminated air, water, soil, food and consumer products. Occupational exposure is a common cause of lead poisoning in adults. One of the largest threats to children is lead paint that exists in many homes, especially older ones, thus children in older houses with chipping paint are at great risk.

Lead poisoning can present a variety of symptoms and signs which vary depending on the individual and the duration of lead exposure. Symptoms are non-specific and may be subtle, and someone with elevated lead levels may have no symptoms. Symptoms may be different in adults and children, the main symptoms in adults are headache, abdominal pain, memory loss, kidney failure, male reproductive problems, and weakness, pain or tingling in the extremities. The classic signs and symptoms in children are loss of appetite, abdominal pain, vomiting, weight loss, constipation, anemia, kidney failure, irritability, lethargy, learning disabilities, and behaviour problems. Children may also experience hearing loss, delayed growth, drowsiness, clumsiness, or loss of new abilities, especially speech skills. Symptoms may appear in children at lower blood lead levels than in adults.

Although, numerous investigations have been carried out on health impacts of lead and other heavy metals on humans, soils in the vicinity of painted houses which are intimately linked to children's environment have not really been investigated as one of the sources of lead, cadmium, and other heavy metals. The absence of any known study on heavy metals in soils in the vicinity of the painted buildings coupled with the fact that these painted houses dominate children environment propels the need for this research. This study was therefore designed to ascertain the levels of cadmium, chromium, copper, manganese, nickel, lead and zinc of soils in the vicinity of painted houses in the study area.

\subsection{Sample collection}

\section{Materials and methods}

Soil samples were collected from four local governments cut across two states i.e Gboko, Katsina-ala, in Benue state and Wukari and Ibi local government in Taraba state. Soil samples were collected from commercial places (Schools, churches, mosques) and private (residential places). Sampling spots of about 10$20 \mathrm{~m}$ apart from each other were mapped out for sample collection using clean stainless steel trowel from about $0-15 \mathrm{~cm}$ depth. Soil sample for control sites were collected from where farming, mining, industrial and building activities were absent. The collected sub-samples were then pooled together to form a composite of each individual sample. The samples were mixed thoroughly and stored in polyethylene bags.

\subsection{Sample preparation}

The soil samples were air-dried for weeks, to remove excess moisture. Large soil clogs were also crushed to facilitate the drying. The dried soil samples were crushed in a porcelain mortar using a pestle. Portions of the crushed soil sample were further pulverized to fine powder and passed through a $0.5 \mathrm{~mm}$ sieve for total metal content analysis.

\subsection{Method}

The method developed by the United State Environmental Protection Agency for (total sobbed) heavy metals in soil, sediments, and sludge [11] was used in the preparation of the samples for the determination of total metal contents in this study. One gram $(1.000 \mathrm{~g})$ of the soil samples was weighed into a beaker for acid digestion. Analar grade nitric acid, hydrogen peroxide (about 30\%) and concentrated hydrochloric acid were used for the digestion. The digest was filtered through what man filter paper. Each filtrate was collected in $100 \mathrm{ml}$ volumetric flask and deionised water was used to rinse the filter paper into a volumetric flask. Each filtrate was later made up to $100 \mathrm{ml}$ with deionised water. Standards were prepared with serial dilution techniques within the range of each metal determined. The standards used were analar grade; the instrument was first calibrated with stock solutions of the prepared standards before analysis using Flame Atomic Absorption Spectrophotometer. After every five samples analyzed using FAAS, the first sample was repeated for quality check. Only when the result was within $10 \%$ of earlier readings did the analysis proceed further. The data obtained in the study were analyzed using mean, standard deviation and Pearson correlation analysis. The enrichment factors $(\mathrm{EF})$ of elements in the soils were calculated according to the following equation.

$\mathrm{Efc}=\left(\mathrm{C}_{\mathrm{X}} / \mathrm{C}_{\mathrm{Fe}}\right)_{\text {soil }} /\left(\mathrm{C}_{\mathrm{X}} / \mathrm{C}_{\mathrm{Fe}}\right)_{\text {Earth's crust }}$

Where $\left(\mathrm{C}_{\mathrm{x}} / \mathrm{C}_{\mathrm{Fe}}\right)_{\text {soil }}$ is the ratio of concentration of the element being determined $\left(\mathrm{C}_{\mathrm{x}}\right)$ to that of $\mathrm{Fe}\left(\mathrm{C}_{\mathrm{Fe}}\right)$ in the soil sample and $\left(\mathrm{C}_{\mathrm{x}} / \mathrm{C}_{\mathrm{Fe}}\right)$ earth's crust is the ratio in the reference Earth's crust $[12,13]$. Enrichment factors were calculated for each sample relative to the abundance of the elements in the Earth's crust [14]. Fe was chosen as reference element due to its dominance in the earth crust. The iron content of soils does not change 
owing to its high levels in the Earth's crust, example, $0.5-10 \%$, unless there is a large point source around a specific environment. An enrichment factor of unity would indicate that the relative concentration of a given metal is identical to that which is present in unpolluted soil.

\section{Results and discussion}

Generally, in the four areas studied as presented in tables 1 and 2, the concentration of the heavy metals were extremely high especially $\mathrm{Pb}, \mathrm{Cd}, \mathrm{Zn}$ and $\mathrm{Cr}$, this is an indication that these heavy metals are the primary contaminants in the soils around painted buildings which was also reflected in the low level of these heavy metals obtained from the control sites when compared with those obtained from the study sites. Also the degree of heavy metal concentration in soil around painted buildings which were determined by its enrichment factors was also high. From the mean values and enrichment factor values, there is a clear indication that $\mathrm{Pb}, \mathrm{Cd}, \mathrm{Zn}$ and $\mathrm{Cr}$ are the great contaminants in the soils around painted buildings where washing of the paint from such buildings into surrounding soils easily occurred either by rains or winds causing metal accumulations especially lead in the immediate environment. The enrichment factor in soils from Gboko and Katsina-Ala were found to be in the order of $\mathrm{Pb}>\mathrm{Zn}>\mathrm{Cd}>\mathrm{Cr}$ while those of Ibi and Wukari was found to be in the order $\mathrm{Pb}>\mathrm{Cd}>\mathrm{Zn}>\mathrm{Cr}$. In all cases the enrichment factor of lead in the soils was far more than the other metals studied in the soil. In accordance with contamination categories presented by Sutherland [15] whereby enrichment factors were categorised as $\mathrm{Ef}<2$ (depletion to mineral enrichment), $2 \leq \mathrm{Ef}<5$ (moderate enrichment), $5 \leq \mathrm{EF}<20$ (significant enrichment), $20 \leq \mathrm{EF}<40$ (very high enrichment) it was glaring that the soils were highly enriched with lead. Zinc, cadmium and chromium enriched the soils significantly; Copper and Nickel moderately while manganese depleted to mineral enrichment.

The concentrations of $\mathrm{Cu}, \mathrm{Ni}$ and $\mathrm{Mn}$ were low in soils around painted buildings, so also their enrichment factor values, which do not have much variation although their enrichment factor values were greater than unity; this indicates that the metal is abundant in the soil relative to that found in the earth's crust. Correlation was observed between the various heavy metals under consideration (Table 3). There was strong positive correlation between $\mathrm{Pb}$ and $\mathrm{Cd}$ on one hand and $\mathrm{Cr}$ and $\mathrm{Zn}$ on the other at $\mathrm{p}<0.1$ in the Gboko sample. This is an indication that there was a significant influence of one metal on another suggesting the possibility of the metals coming from the same source. The correlation coefficient between $\mathrm{Pb}$ and $\mathrm{Cd}$ and $\mathrm{Cr}$ and $\mathrm{Zn}$ in the soils around the painted buildings was statistically significant. Though a weak correlation was established for the metals in all the other sites, it can be argued that $\mathrm{Pb}, \mathrm{Cd}, \mathrm{Cr}$ and $\mathrm{Zn}$ were contaminants which were probably released into the soils from the painted buildings.

However, when the levels of these heavy metals obtained in this study were compared with values reported in literature, $\mathrm{Pb}$ and $\mathrm{Cd}$ levels were found to be above a concentration range of 30.000-300.000 mg/g and $3.000 \mathrm{mg} / \mathrm{g}$ respectively [16] and well above permissible recommended levels for soils [17]. Nickel (Ni), and chromium (Cr) were found to be below the critical permissible concentration of 50.000 and $400.000 \mathrm{mg} / \mathrm{g}$ respectively [18] and [19]. Though these heavy metal concentrations fell below the critical permissible concentration level, their persistence in the soils around painted buildings may lead to increased uptake of these heavy metals by humans especially children playing in such environment. There is no doubt that many children in painted houses receive highest doses of lead contaminated dusts compared to their counterparts in the unpainted houses.

\section{Conclusion}

The results obtained from the analysis of soils around the painted buildings in various locations in Gboko, Katsina- ala, Wukari and Ibi local government areas of Benue and Taraba states in Nigeria indicated that the concentrations of $\mathrm{Cd}, \mathrm{Cr}, \mathrm{Cu}, \mathrm{Mn}, \mathrm{Ni}, \mathrm{Pb}$ and $\mathrm{Zn}$ were higher than those of soils from control areas. The degree of contamination of $\mathrm{Pb}$ was the highest. $\mathrm{Cd}, \mathrm{Zn}$, and $\mathrm{Cr}$ also showed high degree of contamination in the soils around the painted buildings. From this reason, it could be predicted that the contaminations of $\mathrm{Pb}, \mathrm{Cd}, \mathrm{Zn}$, and $\mathrm{Cr}$ are probably from anthropogenic sources, while those of $\mathrm{Cu}, \mathrm{Ni}$, and $\mathrm{Mn}$ may not be much, as its contribution from anthropogenic sources. The observed contaminants were $\mathrm{Pb}, \mathrm{Cd}, \mathrm{Zn}$ and $\mathrm{Cr}$ and their concentrations and enrichment factors were high in all the soils studied. Hence, overall, levels of $\mathrm{Pb}, \mathrm{Cd}, \mathrm{Zn}$ and $\mathrm{Cr}$ contaminations are those which call for closer monitoring in sites under considerations.

Table 1: Total metal contents $(\mathrm{mg} / \mathrm{g})$ of soils around painted buildings in the study areas

\begin{tabular}{|c|c|c|c|c|c|c|c|}
\hline \multicolumn{8}{|c|}{ Gboko, $n=15$} \\
\hline Metals & Cd & $\mathrm{Cr}$ & $\mathrm{Cu}$ & Mn & $\mathbf{N i}$ & $\mathbf{P b}$ & Zn \\
\hline Range & $\begin{array}{l}2.400- \\
3.500\end{array}$ & $\begin{array}{l}15.500- \\
34.000\end{array}$ & $\begin{array}{l}43.000- \\
70.000\end{array}$ & $\begin{array}{l}109.000- \\
233.000\end{array}$ & $15.000-25.000$ & $205.000-321.000$ & $122.000-213.000$ \\
\hline $\begin{array}{l}\text { Mean } \\
+ \text { SD }\end{array}$ & $\begin{array}{l}2.853 \\
\pm \\
0.338\end{array}$ & $\begin{array}{l}24.313 \\
\pm 6.086\end{array}$ & $\begin{array}{l}55.533 \pm \\
8.830\end{array}$ & $\begin{array}{l}191.800 \pm \\
29.238\end{array}$ & $20.000 \pm 3.295$ & $255.800 \pm 35.718$ & $191.067 \pm 25.144$ \\
\hline
\end{tabular}


Heavy Metal Contamination Of Soils Around Painted Buildings In Selected Local Governments

\begin{tabular}{|c|c|c|c|c|c|c|c|}
\hline \multicolumn{8}{|c|}{ Wukari, n=15 } \\
\hline Metals & Cd & $\mathrm{Cr}$ & $\mathbf{C u}$ & Mn & $\mathbf{N i}$ & $\mathbf{P b}$ & $\mathbf{Z n}$ \\
\hline Range & $\begin{array}{l}2.890- \\
4.450\end{array}$ & $\begin{array}{l}18.500- \\
34.100\end{array}$ & $\begin{array}{l}49.550- \\
62.110\end{array}$ & $\begin{array}{l}199.760- \\
299.540\end{array}$ & $14.800-21.860$ & $214.670-298.560$ & $121.110-167.770$ \\
\hline $\begin{array}{l}\text { Mean } \\
+{ }_{ \pm} \text {SD }\end{array}$ & $\begin{array}{l}3.813 \\
+ \\
0.474\end{array}$ & $\begin{array}{l}26.805 \\
+\quad 5.732\end{array}$ & $\begin{array}{l}56.023 \pm \\
5.009\end{array}$ & $\begin{array}{l}257.736 \pm \\
33.414\end{array}$ & $18.423 \pm 2.102$ & $262.625 \pm 27.215$ & $142.493 \pm 16.617$ \\
\hline
\end{tabular}

\begin{tabular}{|l|l|l|l|l|l|l|l|}
\hline \multicolumn{8}{|c|}{ Katsina-Ala, $\mathbf{n}=15$} \\
\hline Metals & $\mathrm{Cd}$ & $\mathrm{Cr}$ & $\mathrm{Cu}$ & $\mathrm{Mn}$ & $\mathrm{Ni}$ & $\mathrm{Pb}$ & $\mathrm{Zn}$ \\
\hline Range & $2.700-$ & $15.200-$ & $40.500-$ & $198.400-$ & $15.500-28.500$ & $198.000-284.520$ & $110.950-132.880$ \\
& 4.500 & 35.600 & 75.500 & 298.000 & & & \\
\hline Mean & 3.620 & 24.727 & $61.987 \pm$ & $247.840 \pm$ & $18.487 \pm 2.009$ & $238.674 \pm 30.270$ & $122.398 \pm 7.940$ \\
& \pm & \pm 7.055 & 10.453 & 35.103 & & & \\
\pm SD & 0.628 & & & & & & \\
\hline
\end{tabular}

\begin{tabular}{|c|c|c|c|c|c|c|c|c|c|c|c|}
\hline \multicolumn{12}{|c|}{ Ibi, $\mathbf{n}=15$} \\
\hline Metals & Cd & $\mathrm{Cr}$ & \multicolumn{2}{|c|}{$\mathbf{C u}$} & Mn & \multicolumn{2}{|c|}{$\mathbf{N i}$} & \multicolumn{2}{|c|}{$\mathbf{P b}$} & \multicolumn{2}{|c|}{$\mathbf{Z n}$} \\
\hline Range & $\begin{array}{l}2.900- \\
4.500 \\
\end{array}$ & $\begin{array}{l}15.800- \\
33.750 \\
\end{array}$ & \multicolumn{2}{|c|}{$\begin{array}{l}49.670- \\
71.760 \\
\end{array}$} & $\begin{array}{l}215.330- \\
289.560 \\
\end{array}$ & \multicolumn{2}{|c|}{$14.930-19.450$} & \multicolumn{2}{|c|}{$214.250-281.550$} & \multicolumn{2}{|c|}{$115.670-161.330$} \\
\hline $\begin{array}{l}\text { Mean } \\
\pm \text { SD }\end{array}$ & $\begin{array}{l}3.947 \\
\pm \\
0.464 \\
\end{array}$ & $\begin{array}{l}24.347 \\
\pm 5.457\end{array}$ & \multicolumn{2}{|c|}{$\begin{array}{l}60.873 \pm \\
8.572\end{array}$} & $\begin{array}{l}247.563 \pm \\
23.172\end{array}$ & \multicolumn{2}{|c|}{$16.953 \pm 1.631$} & \multicolumn{2}{|c|}{$245.656 \pm 24.039$} & \multicolumn{2}{|c|}{$138.356 \pm 14.343$} \\
\hline \multicolumn{12}{|c|}{ Soil aggregate $n=60$} \\
\hline Metals & Cd & $\mathrm{Cr}$ & & $\mathbf{C u}$ & Mn & & $\mathrm{Ni}$ & & $\mathbf{P b}$ & & $\mathbf{Z n}$ \\
\hline Range & $\begin{array}{l}2.400 \\
4.500 \\
\end{array}$ & $\begin{array}{l}15.200 \\
35.60\end{array}$ & & $\begin{array}{l}40.500- \\
75.500\end{array}$ & $\begin{array}{l}109 . \\
299 .\end{array}$ & & $14.800-2$ & & $198.540-3$ & & $\begin{array}{l}110.950- \\
213.000\end{array}$ \\
\hline $\begin{array}{l}\text { Mean } \\
\pm \text { SD }\end{array}$ & $\begin{array}{l}3.558 \\
\pm \\
0.638\end{array}$ & $\begin{array}{l}25.04 \\
\pm 6.04\end{array}$ & & $\begin{array}{l}58.604+ \\
8.725\end{array}$ & $\begin{array}{l}236 . \\
39.6\end{array}$ & & $18.466 \pm$ & & $250.689 \pm 3$ & & $\begin{array}{l}148.581 \pm \\
30.797\end{array}$ \\
\hline
\end{tabular}

Table 2: Factors of Accumulation of Heavy Metals around painted buildings in study areas Area: Gboko $\mathrm{n}=15$

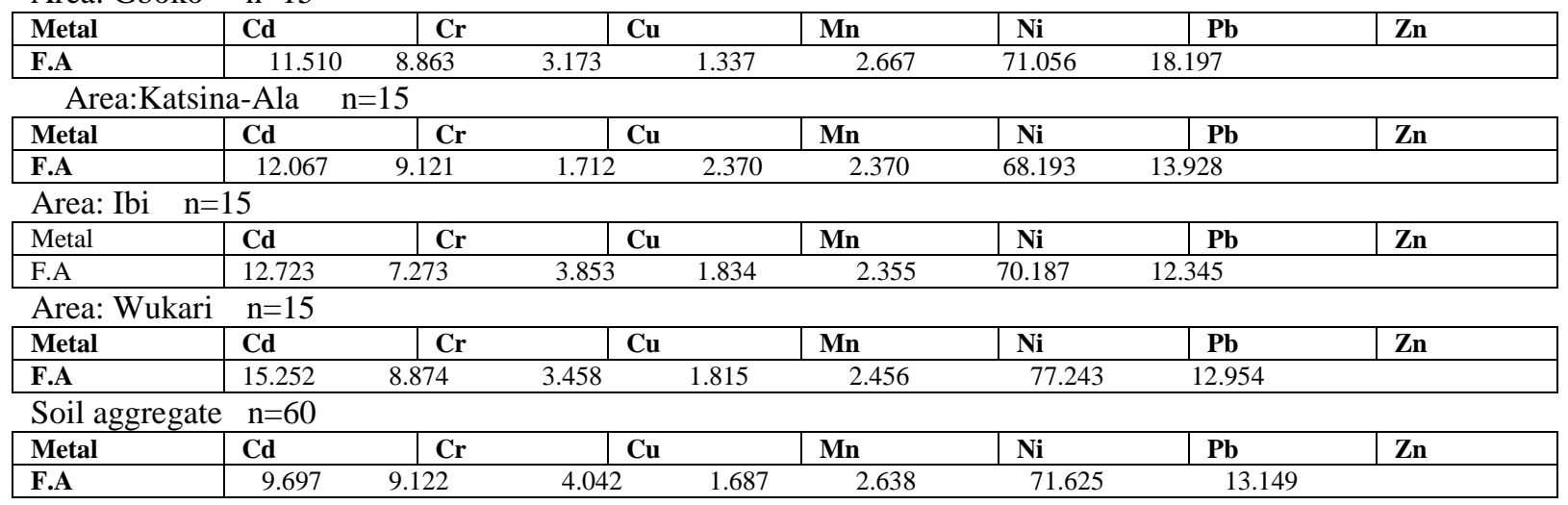

Table 3: Correlation between metal- metal contents in soils around painted buildings in the study areas.

\begin{tabular}{|c|c|c|c|c|c|c|c|}
\hline \multirow[t]{2}{*}{ Point } & $\mathrm{Cd}$ & $\mathrm{Cr}$ & $\mathrm{Cu}$ & $\mathrm{Mn}$ & $\mathrm{Ni}$ & $\mathrm{Pb}$ & $\mathrm{Zn}$ \\
\hline & & 0.045 & -0.460 & 0.442 & -0.366 & 0.630 & -0.444 \\
\hline \multirow[t]{6}{*}{ Gboko } & & & 0.303 & 0.276 & 0.403 & -0.085 & 0.276 \\
\hline & & & & -0.029 & 0.395 & -0.436 & 0.545 \\
\hline & & & & & -0.099 & 0.432 & -0.252 \\
\hline & & & & & & -0.394 & 0.187 \\
\hline & & & & & & & -0.361 \\
\hline & & -0.026 & 0.003 & -0.007 & 0.187 & -0.152 & -0.196 \\
\hline \multirow[t]{4}{*}{ Katsina Ala } & & & 0.031 & -0.273 & 0.219 & -0.409 & 0.202 \\
\hline & & & & 0.418 & -0.079 & -0.218 & -0.249 \\
\hline & & & & & 0.089 & 0.039 & 0.344 \\
\hline & & & & & & -0.154 & -0.046 \\
\hline
\end{tabular}




\begin{tabular}{|c|c|c|c|c|c|}
\hline & -0.156 & 0.006 & 0.198 & 0.055 & -0.417 \\
\hline \multirow[t]{5}{*}{ Wukari } & & -0.490 & 0.423 & 0.234 & 0.450 \\
\hline & & & -0.075 & 0.087 & -0.101 \\
\hline & & & & 0.259 & -0.157 \\
\hline & & & & & 0.216 \\
\hline & & & & & \\
\hline \multirow[t]{5}{*}{ Ibi } & -0.468 & 0.495 & -0.120 & -0.299 & -0.104 \\
\hline & & -0.526 & 0.213 & -0.179 & -0.505 \\
\hline & & & -0.051 & -0.249 & 0.088 \\
\hline & & & & -0.216 & 0.054 \\
\hline & & & & & 0.106 \\
\hline
\end{tabular}

\section{References}

[1]. Odoh R., Agbaji E.B, Kagbu J.A. and Thomas S. A.,(2011); Heavy Metal Speciation in Agricultural Farmland in some selected local government areas of Benue state, Nigeria. Scholars Research Library, Archives of Applied Science Research, 3 (3) 560-573.

[2]. Fergusson,J.E.(1990) Chemistry, Environmental impacts and Health Effects. Pergamon press oxford, 1990, 371-405.

[3]. Oluyemi,E.A.,Fenyit,G.J., Oyekunle,J.A.O and Ogunfowokan,A.O.(2008) Seasonal Variations in heavy metal concentrations in soil and some selected crops at a land fill in Nigeria. African Journal of science and Technology. 2(5):89-96

[4]. Logan T.J. and Miller R.H. (1983) Soil contamination analysis Res. Circ. Ohio Agric. Res. Dev.Ctr.Wooster. 275: 3-15

[5]. Ohio state University (nd) Background levels of heavy metals in Ohio farm soils.http://www.ohioline.osu.edu/rc275/rc275_1.html. Accessed on $18^{\text {th }}$ June 2013.

[6]. W.H.O (World health Organisation),(1995) Evaluation of certain food additives and contaminants(Forty-first report of the joint FAO/WHO expert committee on food additives).WHO Technical report series No 837,WHO, Geneva.

[7]. Ratha,D.S., Venkataraman,G., and Pahala-Kumar,S (1994).Soil contamination due to open cast mining in Goa. A statistical approach to environmental technology.15:853-862

[8]. Fatoki, O.S. (1996) Trace Zinc and copper concentration in roadside surface soils and vegetation measurement of local atmospheric pollution in Alice, South Africa. Environment International, 22(6):759-762.

[9]. Ross, S.M (1994). Toxic metals in soil- plant systems. John Wiley ,New- York

[10]. Opaluwa,O.D and Umar,M.A (2010).Distribution and concentration of Heavy metal in some vegetables and soils from vegetable farms in Tudun Wada keffi, Nigeria. International journal of chemical sciences.3(1):71-77.

[11]. United State Environmental Pollution Agency, USEPA (1986) U.S Government Office, Washington, D.C.

[12]. Martin,H.W., Young,T.R ., and Kaplem,D.I.(1996) Evaluation of three herbaceous index plant species for bioavailability of soil cadmium,Chromium,nickel and vanadium plant and soil. 182:199-207

[13]. Holmgren,G.G.S., Meyer,M.W., Chimey,R.L., and Daniels, R.B .(1993)Cadmium,lead,zinc,copper and nickel in agricultural soils of the united states of America.Journal of Environmental Quality.22:335-348

[14]. Mcbride,M.B(1989) Reactions controlling heavy metal solubility in soils. Advances in soil science.10:1-56

[15]. Sutherland, R.A (2000) Bed sediment-Associated trace metals in an urban stream, Oahu, Hawaii. Environmental Geology, 39:611627

[16]. Kabata-Pendias, A. and Pendias,H. (1984) Trace elements in soils and plants CRC Press Boca Rat On Fla.85:107-1229

[17]. U.S Environmental Protection Agency (1986). Test methods of evaluation for solid waste (USEPA S/W 846 UEPA Washinton D.C

[18]. MAFF and Welch office Agriculture department (1992) Code of Good agricultural practice for the protection of soil. Draft consultation Document, MAFF London.

[19]. EC (Council of the European Communities) (1986): directive 86278 EEC on the protection of the Environment and in particular of the soil when sewage sludge is used.EEC.Brussels. 